\title{
MENINGKATKAN KEMAMPUAN KERJASAMA BELAJAR BIOLOGI MELALUI PENERAPAN STRATEGI INKUIRI TERBIMBING PADA SISWA KELAS VII SMP NEGERI VI KOTA SAMARINDA TAHUN PELAJARAN 2010/ 2011
}

\author{
Elsje Theodora Maasawet \\ Pendidikan Biologi FKIP Universitas Mulawarman Kalimantan Timur
}

\begin{abstract}
Penelitian ini bertujuan untuk mengetahui peningkatkan kemampuan kerjasama dalam belajar biologi melalui penerapan strategi inkuiri terbimbing pada siswa kelas VII semester ganjil SMP Negeri 6 Kota Samarinda Tahun Pelajaran 2010/ 2011. Penelitian tindakan kelas ini dilaksanakan dalam tiga siklus, dalam tiap siklus terdiri dari tiga kali pertemuan, dalam tiap pertemuan peneliti dan observer mengamati kemampuan kerjasama siswa. Sampel dalam penelitian ini adalah keseluruhan siswa kelas VII-6 SMP Negeri 6 Samarinda yang berjumlah 44 orang dari populasi seluruh siswa kelas VII SMP Negeri 6 Samarinda yang berjumlah 343 orang. Hasil penelitian menunujukkan bahwa siklus I dari tiga kali pertemuan diperoleh ratarata kemampuan kerjasama siswa sebesar 12,04\%, siklus II dari tiga kali pertemuan diperoleh rata-rata kemampuan kerjasama siswa dalam belajar biologi sebesar 61,58\% siswa yang mampu, dan pada siklus III dalam tiga kali pertemuan diperoleh rata-rata kemampuan kerjasama siswa sebesar 84,53\% siswa yang mampu. Berdasarkan hasil anlisis data tersebut dapat disimpulkan bahwa terjadi peningkatan kemampuan kerjasama siswa dalam belajar biologi melalui penerapan strategi inkuiri terbimbing.
\end{abstract}

Kata kunci: inkuiri terbimbing, kemampuan kerjasama

Kerjasama adalah salah satu asas didaktik. Kini timbul pertanyaan apakah yang kita gunakan sebagai dasar kerjasama dalam kelas? Menjawab pertanyaan tersebut, Grambs berpendapat sebagai berikut dalam pengajaran disekolah yang demokratis, baik kerjasama maupun persaingan sama pentingnya. Hanya persaingan tidak berarti persaingan antar kelompok. Senada dengan hal tersebut Sriyono (1992) mengemukakan bahwa guru hendaknya menciptakan suasana kerjasama antar murid sehingga pelajaran yang diberikan itu lebih efektif dan efisien. Kerjasama yang dimaksud disini adalah untuk kebaikan, lainnya tidak. Grambs dalam Nasution (2000) Joyce dan Weil (1996) menyatakan tujuan kegiatan belajar di sekolah adalah membantu pelajar memperoleh informasi, ide, keterampilan, cara berpikir, nilai cara mendeskripsikan dirinya, dan cara belajar. Pembelajaran disekolah bertujuan meningkatkan kemampuan siswa belajar lebih mudah dan efektif, sehingga diperoleh pengetahuan dan keterampilan untuk mengkomunikasikannya. Salah satu hal yang menggambarkan siswa memperoleh keterampilan adalah kemampuan bekerjasama dalam belajar.

Inkuiri terbimbing yaitu strategi inkuiri dimana guru membimbing siswa melakukan kegiatan dengan memberi pertanyaan awal dan mengarahkan pada suatu diskusi. Guru mempunyai peran aktif dalam menentukan permasalahan dan tahap-tahap pemecahannya. Strategi inkuiri terbimbing ini digunakan bagi siswa yang kurang berpengalaman belajar dengan strategi inkuiri. Dengan strategi ini siswa belajar lebih beorientasi pada bimbingan dan petunjuk dari guru hingga siswa dapat memahami konsep-konsep pelajaran. Pada strategi ini siswa akan dihadapkan pada tugastugas yang relevan untuk diselesaikan baik melalui diskusi kelompok maupun secara individual agar mampu menyelesaikan masalah dan menarik suatu kesimpulan secara mandiri (Sanjaya, 2008). 
Dalam beberapa jenis inkuiri guru membatasi memberi bimbingan, agar siswa berupaya terlebih dahulu secara mandiri, dengan harapan agar siswa dapat menemukan sendiri penyelesaiannya. Namun, apabila ada siswa yang tidak dapat menyelesaikan permasalahannya, maka bimbingan dapat diberikan secara tidak langsung dengan memberikan contoh-contoh yang relevan dengan permasalahan yang dihadapi, atau melalui kerjasama dan diskusi dengan siswa dalam kelompok lain.

Pembelajaran biologi yang terjadi di SMP Negeri 6 Kota Samarinda adalah guru belum memfasilitasi siswa secara sempurna dalam kemampuan bekerjasama dalam belajar, karena pelajaran biologi dilakukan selama ini adalah masih merupakan praktek pola-pola lama pembelajaran. Praktek pembelajaran yang dilaksanakan, ternyata belum ada upaya guru untuk melatih siswa dalam bekerjasama saat pelajaran biologi baik itu pada saat berdiskusi, maupun dalam kegiatan praktikum. Untuk hal tersebut diperlukan suatu langkah terobosan baru meningkatkan kemampuan kerjasama siswa melalui model pembelajaran Inkuiri terbimbing di kelas VII SMP Negeri 6 Samarinda. Kerjasama adalah salah satu asas didaktik. Lawan dari kata kerjasama ialah persaingan. Jean D Grambs berpendapat bahwa dalam pelajaran di sekolah yang demokratis, baik kerjasama maupun persaingan sama pentingnya. Hanya persaingan tidak berarti persaingan antar kelompok. Tujuan persaingan di sini bukan untuk memperoleh hadiah atau kenaikan tingkat, tetapi untuk mencapai hasil yang lebih tinggi atau pemecahan masalah yang dihadapi (Nasution, 2000). Demikian pula Landsberge (2009) menyatakan kerjasama atau belajar bersama adalah proses beregu (berkelompok) di mana anggota-anggotanya mendukung dan saling mengandalkan untuk mencapai suatu hasil mufakat. Kerjasama adalah saling mempengaruhi sebagai anggota kelompok, maka yang perlu dilakukan dalam bekerjasama adalah sebagai berikut: a) Membangun dan membagi suatu tujuan yang lumrah; b) Sumbangkan pemahaman tentang permasalahan: pertanyaaan, wawasan, dan pemecahan c) Setiap anggota memperkuat yang lain untuk berbicara dan berpartisipasi, dan menentukan kontribusi (sumbangan) mereka. d) Bertanggung jawab terhadap yang lain dan e) Bergantung pada yang lain.

Tujuan dari bekerjasama ialah dapat mengembangkan tingkat pemikiran yang tinggi, keterampilan komunikasi yang penting, meningkatkan minat, percaya diri, kesadaran bersosial dan sikap toleransi terhadap perbedaan individu. Dalam kerjasama, kita memiliki kesempatan mengungkapkan gagasan, mendengarkan pendapat orang lain, serta bersama-sama membangun pengertian, menjadi sangat penting dalam belajar karena memiliki unsur yang berguna menantang pemikiran dan meningkatkan harga diri seseorang. (Efi, 2007).

Bentuk kerjasama dapat dijumpai pada semua kelompok orang dan usia. Sejak masa kanak-kanak, kebiasaan bekerjasama sudah diajarkan di dalam kehidupan keluarga. Setelah dewasa, kerjasama akan semakin berkembang dengan banyak orang untuk memenuhi berbagai kebutuhan hidupnya. Pada taraf ini, kerjasama tidak hanya didasarkan hubungan kekeluargaan, tetapi semakin kompleks. Dasar utama dalam kerja sama ini adalah keahlian, di mana masing-masing orang yang memiliki keahlian berbeda, bekerja bersama menjadi satu kelompok/kelompok dalam menyelesaikan sebuah pekerjaan.

Belajar adalah proses yang ditempuh seseorang dalam menambah ilmu pemgetauan dan pengalamannya serta perubahan secara positif dalam lingkungan sosialnya. Perubahan itu meliputi ranah kognitif, afektif dan psikomotorik.

Inkuiri berasal dari Bahasa Inggris inquiry yang dapat diartikan sebagai proses bertanya dan mencari tahu jawaban terhadap pertnyaan 
ilmiah yang diajukan. Pertanyaan ilmiah adalah pertanyaan yang dapat mengarahkan pada kegiatan penyelidikan terhadap objek pertanyaan. Dengan kata lain, inkuiri adalah proses untuk memperoleh dan mendapatkan informasi dengan melakukan observasi atau eksperimen untuk mencari jawaban atau memecahkan masalah terhadap pertanyaan dengan menggunakan kemampuan berpikir kritis dan logis. (Schmidt, 2003).

Secara umum, inkuiri merupakan proses yang bervariasi dan meliputi kegiatan-kegiatan mengobservasi, merumuskan pertanyaan yang relevan, meng-evaluasi buku dan sumbersumber informasi lain secara kritis, merencanakan penyelidikan atau investigasi, mereview apa yang telah diketahui, melaksanakan percobaan atau eksperimen dengan menggunakan alat untuk memperoleh data, menganalisis dan menginterpretasi data, serta membuat prediksi dan mengkomunikasikan hasilnya.

Sebagai strategi pembelajaran, inkuiri dapat diimplementasikan secara terpadu dengan strategi lain sehingga dapat membantu pengembangan pengetahuan dan pemahaman serta kemampuan melakukan kegiatan inkuiri oleh siswa. Sedangkan sebagai bagian dari materi pelajaran Biologi, inkuiri merupakan kemampuan yang harus dimiliki oleh siswa agar dapat melakukan penyelidikan ilmiah. Sehubungan dengan hal tersebut, Chiapeta \& Adams (2004) menyatakan bahwa pemahaman mengenai peranan materi dan proses sains dapat membantu guru menerapkan pembelajaran yang bermula dari pertanyaan atau masalah dengan lebih baik. Fokus dari empat aspek inkuiri dalam pembelajaran sains.

Inkuiri terbimbing (guided inquiry), di mana siswa diberikan kesempatan untuk bekerja merumuskan prosedur, menganalisis hasil dan mengambil kesimpulan secara mandiri, sedangkan dalam hal menentukan topik, pertanyaan dan bahan penunjang, guru hanya berperan sebagai fasilitator. Pendekatan inkuiri terbimbing yaitu pendekatan inkuiri dimana guru membimbing siswa melakukan kegiatan dengan memberi pertanyaan awal dan mengarahkan pada suatu diskusi. Guru mempunyai peran aktif dalam menentukan permasalahan dan tahap-tahap pemecahannya. Pendekatan inkuiri terbimbing ini digunakan bagi siswa yang kurang berpengalaman belajar dengan pendekatan inkuiri. Dengan pendekatan ini siswa belajar lebih beorientasi pada bimbingan dan petunjuk dari guru hingga siswa dapat memahami konsep-konsep pelajaran. Pada pendekatan ini siswa akan dihadapkan pada tugas-tugas yang relevan untuk diselesaikan baik melalui diskusi kelompok maupun secara individual agar mampu menyelesaikan masalah dan menarik suatu kesimpulan secara mandiri.

Pada dasarnya siswa selama proses belajar berlangsung akan memperoleh pedoman sesuai dengan yang diperlukan. Pada tahap awal, guru banyak memberikan bimbingan, kemudian pada tahap-tahap berikutnya, bimbingan tersebut dikurangi, sehingga siswa mampu melakukan proses inkuiri secara mandiri. Bimbingan yang diberikan dapat berupa pertanyaan-pertanyaan dan diskusi multi arah yang dapat menggiring siswa agar dapat memahami konsep pelajaran biologi. Di samping itu, bimbingan dapat pula diberikan melalui lembar kerja siswa yang terstruktur. Selama berlangsungnya proses belajar guru harus memantau kelompok diskusi siswa, sehingga guru dapat mengetahui dan memberikan petunjuk-petunjuk dan scafolding yang diperlukan oleh siswa (Sanjaya, 2008). Sanjaya (2008) menyatakan bahwa pembelajaran inkuiri memiliki sintaks atau langkah-langkah dalam proses pelaksanaannya, adapun langkah-langkah tersebut sebagai berikut:

\section{Orientasi}

Pada tahap ini guru melakukan langkah untuk membina suasana atau iklim pembelajaran yang kondusif. Hal yang dilakukan dalam tahap orientasi ini adalah: 
menjelaskan topik, tujuan, dan hasil belajar yang diharapkan dapat dicapai oleh siswa. Menjelaskan pokok-pokok kegiatan yang harus dilakukan oleh siswa untuk mencapai tujuan. Pada tahap ini dijelaskan langkahlangkah inkuiri serta tujuan setiap langkah, mulai dari langkah merumuskan merumuskan masalah sampai dengan merumuskan kesimpulan. Menjelaskan pentingnya topik dan kegiatan belajar. Hal ini dilakukan dalam rangka memberikan motivasi belajar siswa.

\section{Merumuskan masalah}

Merumuskan masalah merupakan langkah membawa siswa pada suatu persoalan yang mengandung teka-teki. Persoalan yang disajikan adalah persoalan yang menantang siswa untuk memecahkan teka-teki itu. Tekateki dalam rumusan masalah tentu ada jawabannya, dan siswa didorong untuk mencari jawaban yang tepat. Proses mencari jawaban itulah yang sangat penting dalam pembelajaran inkuiri, oleh karena itu melalui proses tersebut siswa akan memperoleh pengalaman yang sangat berharga sebagai upaya mengembangkan mental melalui proses berpikir.

\section{Merumuskan hipotesis}

Hipotesis adalah jawaban sementara dari suatu permasalahan yang dikaji. Sebagai jawaban sementara, hipotesis perlu diuji kebenarannya. Salah satu cara yang dapat dilakukan guru untuk mengembangkan kemampuan menebak (berhipotesis) pada setiap anak adalah dengan mengajukan berbagai pertanyaan yang dapat mendorong siswa untuk dapat merumuskan jawaban sementara atau dapat merumuskan berbagai perkiraan kemungkinan jawaban dari suatu permasalahan yang dikaji.

\section{Mengumpulkan data}

Mengumpulkan data adalah aktifitas menjaring informasi yang dibutuhkan untuk menguji hipotesis yang diajukan. Dalam pembelajaran inkuiri, mengumpulkan data merupakan proses mental yang sangat penting dalam pengembangan intelektual. Proses pemgumpulan data bukan hanya memerlukan motivasi yang kuat dalam belajar, akan tetapi juga membutuhkan ketekunan dan kemampuan menggunakan potensi berpikirnya.

\section{Menguji hipotesis}

Menguji hipotesis adalah menentukan jawaban yang dianggap diterima sesuai dengan data atau informasi yang diperoleh berdasarkan pengumpulan data. Menguji hipotesis juga berarti mengembangkan kemampuan berpikir rasional. Artinya, kebenaran jawaban yang diberikan bukan hanya berdasarkan argumentasi, akan tetapi harus didukung oleh data yang ditemukan dan dapat dipertanggungjawabkan.

\section{Merumuskan kesimpulan}

Merumuskan kesimpulan adalah proses mendeskripsikan temuan yang diperoleh berdasarkan hasil pengujian hipotesis. Untuk mencapai kesimpulan yang akurat sebaiknya guru mampu menunjukkan pada siswa data mana yang relevan. Pengembangan sikap inkuiri di kelas, guru mempunyai peranan sebagai konselor, konsultan dan teman yang kritis. Guru harus dapat membimbing dan merefleksikan pengalaman kelompok melalui tiga tahap: (1) Tahap problem solving atau tugas; (2) Tahap pengelolaan kelompok; (3) Tahap pemahaman secara individual, dan pada saat yang sama guru sebagai instruktur harus dapat memberikan kemudahan bagi kerja kelompok, melakukan intervensi dalam kelompok dan mengelola kegiatan pengajaran.

\section{METODE}

Jenis penelitian yang digunakan adalah penelitian tindakan kelas (PTK). Waktu penelitian ini bulan Januari sampai April 2011. Penelitian ini bertempat di SMP Negeri 6 Samarinda. Subjek penelitian ini 
adalah siswa kelas VII SMPN 6 Samarinda Tahun Pembelajaran 2010/ 2011 semester genap. Tahapan penelitian sebagai berikut: Penelitian ini berlangsung 3 siklus. Tiap siklus dilaksanakan sesuai dengan perubahan yang ingin dicapai. Adapun prosedur tindakan dimulai dari (1) perencanaan tindakan, (2) pelaksanaan tindakan, (3) pengamatan dan evaluasi, serta (4) analisis dan refleksi. Dalam tahap pelaksanaan penelitian, peran peneliti adalah:(1) merancang pelaksanaan pembelajaran Keanekaragaman pada tingkat organisasi kehidupan dengan strategi inkuiri terbimbing; (2) bekerja dengan praktisi dalam melaksanakan tindakan yang direncanakan.

\section{Perencanaan Siklus I}

Perencanaan tindakan siklus I meliputi pembuatan Rencana Program Pembelajaran (RPP), membuat format pembelajaran, serta mempersiapkan materi dan alat-alat/bahan yang dibutuhkan siswa selama proses pembelajaran.

\section{Pelaksanaan Tindakan Siklus I}

Dalam tahap pelaksanaan tindakan, peran peneliti adalah; (1) merancang teknik yang digunakan dalam pembelajaran, (2) bekerjasama dengan guru dalam pelaksaan tindakan, (3) peneliti berperan sebagai guru dalam kegiatan pembelajaran untuk memberikan pengarahan, motivasi, dan stimulus, agar peneliti dapat melaksanakan perannya berdasarkan rencana. Tindakan yang dilakukan pada siklus I ini adalah melaksanakan aktivitas pembelajaran dengan strategi inkiri terbimbing dengan materi "jaringan pada tumbuhan dan jaringan pada hewan”, siswa mengamati gambar charta bagian-bagian jaringan pada tumbuhan dan jaringan pada hewan. Penggunaan charta ini sebagai langkah awal dalam pelaksanaan tindakan, alasan pemilihan media charta agar siswa mampu membanyangkan gambaran secara umum bentuk dan bagian sel makhluk hidup itu sendiri. Materi diambil dari buku paket.

\section{Kegiatan Pengamatan ( Observasi)}

Pada tahap pengamatan menggunakan lembar observasi untuk guru dan untuk siswa. Kedua instrument tersebut merupakan data dari setiap pertemuan untuk kekurangankekurangan dan kemajuan proses pembelajaran, lembar observasi itu pula yang digunakan untuk mengetahui kemampuan kerjasama siswa dan pemberian evaluasi tiap siklus.

\section{Refleksi}

Pada tahap refleksi peneliti bersama pengamat mendiskusikan hasil-hasil yang diperoleh baik berupa kemajuan dan perubahan proses pembelajaran untuk guru dan siswa dan kekurangan-kekurangan yang ditemukan dari hasil observasi untuk setiap pertemuan pada siklus tindakan semua kekurangan-kekurangan atau kelemahankelemahan direncanakan perbaikan dan dilaksanakan untuk setiap pertemuan pada siklus berikutnya.

Pada tahap refleksi ini peneliti menggunakan kriteria berikut :

1. Saling memberi informasi sesama anggota.

2. Perselisihan yang terjadi dapat terselesaikan.

3. Tercipta suasana kerjasama yang akrab dan moral kerja yang baik dalam kelompok.

4. Meminta/ memberikan ide dan pendapat kepada semua anggota kelompok untuk membantu membuat keputusan.

5. Mendukung keputusan kelompok.

6. Menghargai masukan dan keahlian anggota lain.

7. Berpartisipasi dalam melaksanakan tugasnya.

8. Menghargai hasil yang dicapai oleh kelompok. 
Teknik Pengumpulan Data

Pengumpulan data dalam penelitian ini dilakukan

melalui

lembar observasi untuk mengetahui situasi pembelajaran yang diambil pada saat tindakan. Observasi dilakukan selama kegiatan pembelajaran setiap putaran. Untuk mengetahui proses belajar dan kerjasama siswa dalam pembelajaran inkuiri terbimbing. Reduksi data yakni rekapan data yang dimiliki oleh guru biologi berupa nilai rata-rata pelajaran biologi selama penelitian berlangsung.

\section{Penarikan kesimpulan}

Kegiatan terakhir dalam analisis data adalah penarikan kesimpulan dan verifikasi. Dari data yang diperoleh kemudian diolah secara sistematis, sehingga dapat dipahami dan ditarik kesimpulan dari penelitian yang dilakukan.

\section{Indikator Keberhasilan}

Indikator yang menjadi tolak ukur dalam menyatakan bahwa pembelajaran berlangsung selama penelitian berhasil meningkatkan kemampuan kerjasama siswa, jika aspek-aspek dari kemampuan kerjasama telah terpenuhi, aspek tersebut adalah interaksi sosial, keterlibatan, kepercayaan, pengertian, dan tanggung jawab. Untuk mengetahui kriteria kemampuan kerjasama itu telah terpenuhi atau tidak, peneliti menggunakan kriteria yang diadopsi dan dimodifikasi oleh peneliti.

1. Saling memberi informasi sesama anggota

2. Perselisihan yang terjadi dapat terselesaikan

3. Tercipta suasana kerjasama yang akrab dan moral kerja yang baik dalam kelompok

4. Meminta/ memberikan ide dan pendapat kepada semua anggota kelompok untuk membantu membuat keputusan

5. Mendukung keputusan kelompok
6. Menghargai masukan dan keahlian anggota lain

7. Berpartisipasi dalam melaksanakan tugasnya

8. Menghargai hasil yang dicapai oleh kelompok

Indikator lain yang menjadi tolak ukur dalam menyatakan bahwa pembelajaran yang berlangsung dapat meningkatkan kemapuan kerjasama siswa dengan berdasar pada peningkatan prestasi belajar siswa, jika telah terjadi peningkatan nilai rata-rata setiap siklus dari nilai rata-rata sebelumnya dalam proses pembelajaran inkuiri terbimbing. Untuk mengetahui kriteria hasil belajar siswa itu baik atau tidak peneliti menggunakan kriteria Sujana yang diadopsi dan dimodifikasi oleh peneliti.

Teknik analisis data yang digunakan dalam penelitian ini adalah teknik statistik deskriptif yang artinya hanya memaparkan data yang diperoleh melalui observasi dan rata-rata hasil belajar. Reduksi data adalah proses penelitian, perumusan perhatian data yang muncul dari catatan yang tertulis di lapangan selama penelitian berlangsung. Reduksi data juga merupakan bentuk analisis data yang menajamkan, menggolongkan, mengarahkan, membuang data yang tidak perlu dan mengorganisasikan data sedemikiam rupa sehingga kesimpulan akhirnya dapat diveivikasi. Berdasarkan hal tersebut reduksi data yang dimaksud dalam penelitian ini ialah proses mereduksi, mengelompokkan dan merangkumkan data yang diperoleh dilapangan melalui hasil observasi yang dilaksanakan oleh peneliti dan observer selama pelaksanaan tindakan.

Data yang diperoleh melalui observasi dan tes hasil belajar dipaparkan secara sedehana dalam bentuk paparan naratif, yaitu disajikan dalam bentuk tabel dan kalimat sederhana untuk setiap putaran. Analisis data sekunder yang merupakan rata-rata hasil belajar siswa merupakan data kuantitatif 
menggunakan statistik deskriptif. Rata-rata digunakan untuk mengetahui hasil belajar siswa dalam satu kelas dan untuk mengetahui peningkatan hasil belajar dengan membandingkan rata-rata skor hasil belajar masing-masing siklus. Dalam penelitian tindakan kelas ini data dikumpulkan dengan menggunakan instrument penelitian utama dan instrument penelitian penunjang. Instrument penelitian utama adalah peneliti.

\section{HASIL}

Penelitian tindakan kelas ini terdiri dari tiga siklus. Setiap siklus dilaksanakan dengan tiga kali pertemuan tiap siklusnya. Setiap pertemuan siswa diperhatikan kemampuan kerjasamanya. Selanjutnya data dianalisis untuk mengetahui peningkatan kemampuan kerjasama siswa dalam proses pembelajaran yang diperoleh setiap siklus. Adapun hasil penelitian tiap siklus adalah sebagai berikut:

\section{Siklus I}

\section{Kemampuan kerjasama siswa}

Siklus I terdiri dari tiga kali pertemuan dimana pengamatan kemampuan kerjasama siswa dilakukan setiap pertemuan dan di akhir siklus diadakan evaluasi, dimana hasil evaluasi ini akan dijadikan data untuk nilai hasil belajar siswa pada siklus I. Hasil pengamatan pada siklus I diperoleh dari skor rata-rata dari setiap pertemuan yang mencakup delapan indikator pengamatan yang merupakan hasil modivikasi peneliti. Indikator tersebut sebagai berikut:

1. Saling memberi informasi sesama anggota

2. Perselisihan yang terjadi dapat terselesaikan

3. Tercipta suasana kerjasama yang akrab dan moral kerja yang baik dalam kelompok
4. Meminta/ memberikan ide dan pendapat kepada semua anggota kelompok untuk membantu membuat keputusan

5. Mendukung keputusan kelompok

6. Menghargai masukan dan keahlian anggota lain

7. Berpartisipasi dalam melaksanakan tugasnya

8. Menghargai hasil yang dicapai oleh kelompok

Pada siklus I diperoleh data hasil pengamatan dengan menggunakan skor 1-5, adapun kriteria dari setiap skor adalah sebagai berikut:

1. Skor 1- 1,99: Sangat Tidak Mampu, artinya siswa betul-betul tidak mengerti/ melaksanakan indikator tersebut

2. Skor 2-2,9 : Belum Mampu, artinya siswa sudah mengerti akan indikator tersebut tapi belum dilaksanakan

3. Skor 3- 3,9 : Cukup Mampu, artinya siswa sudah mengerti dengan indikator tersebut akan tetapi dilaksanakan apabila ada perintah

4. Skor 4-4,9 : Mampu, artinya siswa sudah paham dan melaksanakannya dengan adanya bimbingan

5. Skor 5 : Sangat Mampu, artinya siswa dapat secara mandiri melakukan indikator tersebut.

\section{Siklus II}

\section{Kemampuan kerjasama siswa}

Berdasarkan hasil refleksi dari siklus I maka pengamatan pada siklus II juga dilaksanakan dengan 3 kali pertemuan. Hasil pengamatan kemampuan kerjasama belajar biologi siswa melalui penerapan strategi inkuiri terbimbing ialah sebagai berikut: 
Pertemuan 1 pada siklus yang kedua diperoleh hasil pengamatan untuk skor 3 yang berarti cukup sebanyak 6 indikator, semenetara untuk skor 4 yang berarti mampu melaksanakan kerjasama hanya 3 indikator. Dari hasil pengamatan kemampuan kerjasama siswa dalam belajar biologi pada pertemuan 1untuk siklus yang kedua menunjukkan adanya perubahan yang cukup signifikan menuju peningkatan kemampuan kerjasama siswa meskipun masih ditemukan beberapa siswa yang belum mampu menerapkan dengan baik beberapa indikator dalam kerjasama.

Pada pertemuan kedua hasil pengamatan kemampuan kerjasama siswa dalam belajar biologi yakni untuk skor 3 ada empat indikator, dan untuk skor 4 juga ada empat indikator, hal ini menunjukkan bahwa peningkatan kemampuan kerjasama siswa semakin meningkat, yakni dari delapan indikator kerjasama, sebagian sudah mampu dilaksanakan oleh siswa. Pertemuan yang ketiga hasil pengamatan kemampuan kerjasama siswa dalam belajar biologi yakni untuk skor 3 tidak ada lagi, semua indikator pengamatan memperoleh skor 4 dengan kriteria mampu. Dalam pelaksanaan pemberian tindakan untuk mengamati kerjasama siswa dalam belajar biologi melalui penerapan strategi inkuiri terbimbing bisa dikatakan sudah mengalami peningkatan, meskipun pada saat proses pembelajaran berlangsung masih ditemukan beberapa kekurangan.

Secara keseluruhan hasil observasi untuk tiga kali pertemuan pada siklus II diperoleh skor rata-rata 3.95, artinya masih dalam kriteria cukup. Dari hasil pengamatan ini membuktikan terjadinya peningkatan kerjasama siswa dalam proses pembelajaran yang berlangsung selama tiga kali pertemuan didapatkan persentase rata-rata sementara sebesar 61,58\% yang artinya kurang lebih 26 siswa yang telah mampu bekerjasama dalam belajar biologi melalui penerapan strategi inkuiri terbimbing.

\section{Hasil belajar siswa}

Berdasarkan analisis data hasil belajar pada siklus II dimana data ini digunakan sebagai data sekunder pada tiap siklus untuk memperlihatkan peningkatan kemampuan kerjasama dalam belajar biologi melalui penerapan strategi inkuiri terbimbing mesti diikuti dengan peningkatan hasil belajar dari siswa. Pada siklus II nilai yang diambil ialah nilai hasil belajar pengerjaan LKS dan nilai tes setiap akhir siklus.

Secara keseluruhan hasil belajar siswa pada siklus II sebanyak 24 orang siswa yang mendapatkan peningkatan poin sebesar 30 poin yang berkriteria sangat baik, dan siswa yang mendapatkan 20 poin peningkatan sebanyak 8 orang, sedangkan untuk peningkatn dengan 10 poin diperoleh 11 orang siswa, sementara masih ada 4 orang siswa yang mendapatkan poin 0 untuk peningkatan hasil belajar siswa dengan kriteria sangat kurang. Apabila dibandingkan dengan siklus I peningkatan hasil belajar siswa dengan penerapan strategi inkuiri terbimbing sudah terlihat, agar lebih jelasnya pengelompokan perolehan hasil belajar siswa dan kriterianya sebagai berikut: sebanyak 9 orang siswa yang memperoleh rentang nilai 80-100 dengan kriteria baik sekali, sebanyak 9 orang siswa memperoleh rentang nilai 70-79 dengan kriteria baik, sedangkan untuk rentang nilai 60-69 diperoleh sebanyak 13 orang siswa dengan kriteria cukup, serta sebanyak 13 orang siswa memperoleh rentang nilai 50-59 dengan kriteria kurang.

\section{Refleksi}

Berdasarkan hasil observasi dan analisis dari para observer maka data yang diperoleh dari siklus II, meskipun hambatan yang ada pada siklus I sebagian besar sudah bisa diatasi, akan tetapi peneliti dan kolabolator memutuskan untuk melanjutkan ke siklus III meskipun dalam pelaksanaan tindakan yang menerapkan strategi inkuiri terbimbing dalam 
meningkatkan kemampuan kerjasama siswa dalam belakjar biologi secara keseluruhan sudah meningkat, akan tetapi dalam pelaksanaannya, masih ada beberapa hambatan yang ditemui di antaranya:

1. Siswa masih terbiasa dengan bimbingan yang diberikan secara penuh pada siklus I dan siklus II.

2. Menurut para observer kemampuan guru dalam mengatur waktu pada kegiatan penutup masih perlu ditingkatkan.

3. Nilai rata-rata peningkatan kemampuan kerjasama siswa untuk siklus I dan Siklus II belum seiring dengan peningkatan hasil belajar siswa Memperhatikan dan menindaklanjuti hambatan-hambatan yang terjadi dalam pelaksanaan pembelajaran yang menerapkan pemebelajaran inkuiri terbimbing pada siklus II, diperlukan adanya perencanaan tindakan dan perbaikan-perbaikan untuk dilaksanakan pada proses pembelajaran untuk siklus III.

\section{Siklus III}

Hasil pengamatan kemampuan kerjasama siswa Pada siklus III juga dilaksanakan tiga kali pertemuan, berdasarkan hasil pengamatan peneliti dan observer pada siklus ketiga maka diperoleh nilai rata-rata kelas yang diambil dari tiga kali pertemuan kemudian nilai tiap pertemuan dirata-ratakan, kemudian rata-rata nilai kemampuan kerjasama siswa tersebut dijadikan data untuk mengetahui kemampuan kerjasama siswa dalam belajar biologi melalui penerapan strategi inkuiri terbimbing pada siklus (putaran) yang ketiga.

Secara keseluruhan hasil pengamatan kemampuan kerjasama siswa pada siklus ketiga diperoleh skor 4 untuk seluruh indikator kemampuan kerjasama dengan rata-rata sebesar 4,20 dengan kriteria mampu. Menurut Sarwanto (2009) mampu menyampaikan dan memahami dengan baik gagasan dan pesan yang disampaikan secara verbal merupakan tolak ukur kemampuan kerjasama, artinya siswa sudah mampu memahami indikator kejasama dan siswa sudah mampu melaksanakan atau menampakkannya dalam proses pembelajaran. Dari hasil ini membuktikan terjadinya peningkatan kemampuan kerjasama siswa yang sangat signifikan dalam proses pembelajaran dan didapatkan persentase rata-rata sebesar $84,53 \%$, artinya ada sekitar 37 orang siswa yang sudah mampu melaksanakan kerjasama melalui penerapan strategi inkuiri terbimbing.

\section{Hasil belajar siswa}

Berdasarkan hasil analisa data hasil belajar siswa pada siklus III setelah dilakukan tindakan diuraiakan sebagai berikut: hasil belajar diperoleh dari 1 kali pertemuan dengan menggunakan nilai rata-rata pada siklus II sebagai nilai dasar pada siklus III, maka nilai akhir rata-rata pada siklus III adalah 71, 90. Dapat dijelaskan bahwa secara keseluruhan hasil belajar siswa pada siklus III yang dilaksanakan dalam tiga kali pertemuan didapatkan sebanyak 23 orang siswa memperoleh peningkatan 30 poin dengan kriteria sangat baik, 10 orang siswa mendapatkan peningkatan 20 poin, sedangkan untuk peningkatan 10 poin diperoleh sebanyak 3 orang dengan predikat kurang, serta untuk peningkatan 0 poin diperoleh sebanyak 8 orang siswa. Sebanyak 13 siswa mendapatkan nilai dengan rentang 80-100 yang berkriteria sangat baik, sebanyak 14 orang siswa mendapatkan nilai dengan rentang 70-79 yang berkriteria baik, sementara ada 10 orang siswa yang mendapatkan nilai dengan rentang 60-69 yang berkriteria cukup, serta 7 dari 44 rang siswa yang masih mendapatkan nilai dengan rentang 50-59 yang berkriteria kurang pada siklus III. Hal ini membuktikan bahwa peningkatan kerjasama siswa dalam belajar seiring dengan peningkatan hasil belajar siswa yang dijadikan 
data sekunder pada penelitian tindakan kelas ini.

\section{Refleksi}

Penelitian tindakan kelas yang dilaksanakan dalam tiga siklus hasil analisis dan observasi data, peneliti dan kolaborator sepakat untuk mengakhiri pemberian tindakan pada siklus III. Menurut Madya (2010) keberhasilan dalam penelitian tindakan kelas adalah tercapainya peningkatkan kualitas pelaksanaan pembelajaran dalam kelas, dalam hal ini peningkatan kemampuan aktivitas guru pada saat pembelajaran dalam kelas yang menerapkan strategi inkuiri terbimbing, dapat meningkatkan kemampuan kerjasama belajar biologi pada siswa kelas VII SMP Negeri 6 Samarinda Semester Ganjil Tahun Pembelajaran2010/2011.

\section{Analisis Peningkatan Siklus I, II, dan III}

Peningkatan hasil pengamatan kemampuan kerjasama siswa setiap siklus Secara keseluruhan hasil pengamatan untuk kemampuan kerjasama siswa selama tiga siklus tindakan dalam penelitian tindakan kelas (siklus I, siklus II dan siklus III) menggambarkan adanya perubahan yang menunjukkan indikasi peningkatan kemampuan kerjasama siswa dalam belajar biologi melalui penerapan strategi inkuiri terbimbing.

Peningkatan kemampuan kerjasama siswa dalam belajar biologi dapat dijelaskan bahwa (1) siklus I yang dilaksanakan dalam tiga kali pertemuan dari 44 orang siswa diperoleh rata - rata siswa yang mampu bekerjasama hanya 12,05\% dan yang belum mampu 87,96\%, (2) pada siklus II yang juga berlangsung tiga kali pertemuan dari 44 orang siswa diperoleh rata-rata siswa yang mampu adalah sebesar $61,58 \%$ sedangkan yang tidak mampu sebesar 38,42\%, (3) pada siklus III yang juga tiga kali pertemuan dari 44 orang siswa diperoleh rata-rata siswa yang mampu bekerjasama sama dalam belajar biologi sebesar 84,53\% dan yang belum mampu sebanyak 15,47\%. Kemampuan siswa ini diperoleh setelah pengamatan yang dilakukan secara langsung pada saat siswa sedang melakasanakan kegiatan dalam proses pembelajaran yang kemudian dianalisis oleh peneliti. Data hasil analisis tersebut menunjukkan adanya peningkatan kemampuan kerjasama siswa dalam belajar biologi melalui penerapan strategi belajar inkuiri terbimbing dalam tiga siklus (putaran) pada penelitian tindakan kelas (PTK) yang dilaksanakan dalam satu semester yakni semester ganjil pada Tahun Pembelajaran 2010/2011.

\section{PEMBAHASAN}

Penelitian ini merupakan penelitian tindakan kelas (PTK) yang dilaksankan di SMP Negeri 6 Samarinda di mulai pada tanggal 25 Januari 2011 sampai April 2011. Dalam penerapan strategi inkuiri terbimbing haruslah mengutamakan kompetensi dasar dan tujuan pembelajaran yang akan dicapai oleh peserta didik sehingga tema berfungsi sebagai pemersatu peserta didik dapat meningkatkan kerjasama dalam belajar biologi, yang tentu diikuti dengan peningkatan hasil belajar. Langkah-langkah dalam pelaksanaan strategi inkuiri terbimbing ialah orientasi, merumuskan masalah, merumuskan hipotesis, mengumpulkan data, menguji hipotesis dan merumuskan kesimpulan. Hasil penelitian secara rinci dibahas sebagai berikut: Siklus I merupakan tahap perencanaan atas permasalahan awal, peneliti membuat skenario pembelajaran yang tertuang pada rencana pelaksanaan pembelajaran (RPP) sebagai komponen kegiatan belajar-mengajar dimulai dari kegiatan awal, kegiatan inti, sampai pada kegiatan penutup. Dalam proses pengajaran mata pelajaran IPA Biologi yang disajikan untuk tiga kali pertemuan pada siklus I, pada setiap pertemuan akan diberikan tugas berupa pengamatan sesuai dengan indikator pembelajaran, tugas ini dilaksanakan dalam 
kelompok yang terdiri dari 6-7 orang siswa, hasil pengamatan tersebut akan dibuat laporan ilmiah.

Selain tugas pada setiap pertemuan juga diadakan tes akhir siklus untuk melihat hasil belajar siswa. Selain RPP peneliti dalam setiap pertemuan mempersiapkan lembar pengamtan kerjasama siswa, lembar observasi untuk aktivitas guru. Peneliti bertindak sebagai pengajar dalam melaksanakan kegiatan proses pembelajaran sesuai dengan skenario pembelajaran sesuai yang tertuang dalam rencana pelaksanaan pembelajaran setiap pertemuan. Pada saat pembelajan berlangsung peneliti mengamati Kemampuan kerjasama siswa dalam belajar biologi pada siklus I dinilai masih kurang karena banyaknya indikator-indikator pengamtan untuk kerjasama siswa dalam proses pembelajaran masih belum nampak dilakukan. Terlihat pada hasil analisis data kemampuan kerjasama siswa pada pertemuan pertama $100 \%$ dari jumlah 44 orang siswa masih belum mampu bekerjasama dalam proses pembelajaran. Hal tersebut disebabkan karena siswa betul-betul belum mengenal strategi inkuiri terbimbing yang diterapkan. Pada pertemuan kedua sampai pertemuan ketiga sudah ada beberapa siswa yang mampu bekerjasama dalam belajar biologi meskipun masih dalam jumlah yang sedikit yaitu $12,04 \%$ siswa dengan nilai ratarata dari delapan indikator kerjasama yang diamati hanya memperoleh skor 3,41 yang artinya masih dalam kriteria cukup. Dari delapan indikator kerjasama yang terdiri dari (1) saling memberi informasi sesama anggota, (2) perselisihan yang terjadi dapat terselesaikan, (3) tercipta suasana kerjasama yang akrab dan moral kerja yang baik dalam kelompok, (4) meminta/ memberikan ide dan pendapat kepada semua anggota kelompok untuk membantu membuat keputusan, (5) mendukung keputusan kelompok, (6) menghargai masukan dan keahlian anggota lain, (7) berpartisipasi dalam melaksanakan tugasnya, (8) Menghargai hasil yang dicapai oleh kelompok.

Dari hasil rata-rata dari tiga pertemuan pada siklus I diperoleh skor dengan rentang $3 \geq X<4$ untuk semua indikator dengan kriteria cukup. Menurut Sarwanto (2009) dengan penggunaan skala likert dengan rentang 1-5, untuk skor rata-rata $1 \geq X<4$ dikatan belum mampu bekerjasama dalam satu tim kerja maupun dalam menempatkan diri dengan baik sebagai anggota tim kerja. Hal ini mengindikasikan bahwa pada siklus I siswa belum mampu bekerjasama dalam proses pembelajaran biologi melalui penerapan strategi inkuiri terbimbing. Ketidakmampuan siswa bekerjasama dalam proses pembelajaran disebabkan karena siswa masih terbiasa dengan pola pengajaran lama dimana siswa yang menjadi objek penelitian ialah siswa kelas VII SMP yang merupakan siswa peralihan dari sekolah dasar sehingga pola pembelajaran inkuiri terbimbing yang menuntut mereka harus mampu bekerjasama baik itu dalam kegiatan pengamatan atau kegiatan praktikum, maupun dalam kegaiatan diskusi dalam kelompok. Kebanyakan siswa dalam melaksanakan kegiatan pembelajaran belum menampakkan adanya iniasitif untuk bekerjasama dengan siswa yang lainnya. Dalam berdiskusi siswa belum bisa menerima pendapat siswa yang lain, hal ini sesuai dengan teori Sarwanto (2009) ketidakmampuan bekerjasama juga dinilai dari sikap kasar siswa artinya siswa bersikap reaktif terhadap kritik, saran, dan pendapat yang berbeda.

Berdasarkan hasil pengamatan yang telah di analisis pada siklus II menunjukkan adanya peningkatan dibandingkan dengan siklus I. Dalam siklus II perolehan rata-rata skor kemampuan kerjasama siswa ialah untuk skor 3,9 diperoleh sebanyak lima indikator kemampuan kerjasama dengan kriteria cukup, dan untuk skor 4 diperoleh sebanyak tiga indikator pengamatan dengan kriteria mampu bekerjasama. Dari tiga indikator yang 
mendapatkan skor 4 dengan kriteria mampu yaitu indikator siswa mampu saling memberi informasi, berpartisipasi dalam melaksanakan tugasnya, dan menghargai hasil yang dicapai dalam kelompok. Hal ini menunjukkan bahwa ketiga indikator tersebut sudah nampak dilakukan siswa meskipun belum keseluruhan siswa melaksanakannya karena terlihat pada hasil analisis data hanya 61,58\% siswa yang mampu melaksanakan delapan indikator kerjasama dengan rata-rata skor 4 yang artinya sudah mampu melaksanakan kerjasama. Menurut Sarwanto (2009) kerjasama merupakan

kemampuan menyampaikan dan memahami dengan baik gagasan dan pesan yang disampaikan secara verbal dan kemampuan dalam menyikapi dan menghadapi kritik, saran, dan pendapat orang lain yang berbeda dengan yang baik dan sopan. Akan tetapi dalam pelaksanannya peneliti menemukan halhal yang membuat siswa sulit untuk bekerjasama ialah apabila dalam satu kelompok terdapat siswa yang memiliki sifat egois yang cukup tinggi dan tidak mau kalah dengan siswa yang lainnya, hal inilah yang menyebabkan dalam proses pembelajaran siswa tersebut tidak mau saling memberi informasi mengenai apa yang dipelajari. Sedangkan untuk indikator yang belum mampu dilaksakan siswa dengan baik ialah menciptakan suasana kerja yang baik, perselisihan yang terjadi dapat terselesaikan, memberi ide/ gagasan untuk hasil kerja yang baik dan menghargai masukan orang lain.

Dari kelima indikator tersebut yang paling menonjol dalam siklus II yang terdiri dari tiga kali pertemuan ialah indikatortercipta suasana kerja yang akrab dan moral yang baik, dan perselisihan yang terjadi dapat terselesaikan, kedua indikator ini yang menjadi indikator nilai rata-rata terendah dalam siklus II. Hasil belajar siswa pada siklus II mengalami peningkatan dari nilai rata-rata akhir siklus I sebesar 65,66 dengan kriteria cukup menjadi 70,91 yang berkriteia baik.
Rata-rata poin peningkatan sebesar 8,8 berkriteria baik. Berdaarkan hasil observasi dan analisis data pada siklus II ini peneliti dan kolaborator sepakat untuk melanjutkan penelitian ini pada siklus (putaran) selanjutnya, hal ini disebabkan karena adanya beberapa permasalahan yang ditemui pada siklus II, diperlukan adanya perbaikan tindakan untuk dilaksanakan pada siklus III. Menurut Syafri (2008) Jika siklus kedua telah dilakukan, tetapi hasilnya belum memuaskan juga, maka disusun lagi rencana perbaikan untuk siklus berikutnya, sampai diperoleh hasil yang memuaskan. Berdasar dari hambatan-hambatan yang terjadi pada siklus II dalam penerapan strategi inkuiri terbimbing pada siswa kelas VII SMP Negeri 6 Samarinda peneliti merumuskan perencanaan untuk siklus III. Siklus III sebagai respon atas permasalahan-permasalahan pada siklus I dan II, Hasil observasi menunjukkan kemampuan kerjasama siswa pada siklus III mengalami peningkatan yang baik.

Terlihat dari delapan indikator pengamatan diperoleh skor rata-rata dari tiga kali pertemuan ialah 4 untuk semua indikator pengamatan dengan kriteria mampu. Menurut Sarwanto (2009) dengan penggunaan skala likert skor dengan rentang $4 \leq \mathrm{X} \leq 5$ artinya mampu bekerjasama dalam satu tim kerja, serta mampu menempatkan diri dengan baik sebagai anggota tim kerja, mampu menyampaikan dan memahami dengan baik gagasan dan pesan yang disampaikan secara verbal dan mampu menyikapi dan menghadapi kritik, saran, dan pendapat orang lain yang berbeda dengan yang baik dan sopan. Sedangkan prosentase sebesar 84,53\% artinya dari 44 jumlah siswa ada sekitar 37 orang siswa yang sudah mampu memahami dan melaksanakan indikator kemampuan kerjasama dengan baik. Apabila dibandingkan dengan hasil kemamampuan kerjasama siswa pada siklus I dan siklus II hal ini menunjukkan bahwa

kemampuan kerjasama siswa pada siklus III 
dalam belajar biologi melalui penerapan strategi inkuiri terbimbing mengalami peningkatan. Berdasarkan hasil observasi dan analisis data pada siklus III ini peneliti tidak melanjutkan tindakan, karena pelaksanaan tindakan yang diberikan kepada siswa melalui penerapan strategi inkuiri terbimbing dapat meningkatkan kemampuan kerjasama siswa dalam belajar IPA Biologi di kelas VII SMP Negeri 6 Samarinda Tahun Pembelajaran2010/2011. Menurut Whandi (2009) upaya perbaikan apapun yang dilakukan untuk meningkatkan kualitas pendidikan tidak akan memberikan sumbangan yang signifikan tanpa didukung oleh guru yang profesional dan berkualitas

\section{KESIMPULAN DAN SARAN}

\section{Kesimpulan}

Berdasarkan hasil penelitian dan pembahasan pelaksanaan tindakan kelas dapat disimpulkan bahwa terjadi peningkatan kemampuan kerjasama siswa dalam belajar biologi, berdasarkan hasil pengamatan untuk kemampuan kerjasama siswa pada siklus I diperoleh 12,04\% siswa yang mampu, siklus II diperoleh $61,58 \%$ siswa yang mampu, dan siklus III diperoleh $84,53 \%$ siswa yang mampu. Dengan demikian melalui penerapan strategi inkuiri terbimbing kemampuan kerjasama siswa dalam belajar biologi pada kelas VII SMP Negeri 6 Kota Samarinda mengalami peningkatan.

\section{Saran}

Berdasarkan penelitian yang telah dilakukan, penulis menyampaikan beberapa saran sebagai berikut:

1. Bagi guru pada tingkat sekolah menengah pertama agar mengetahui dan menerapkan langkah-langkah penerapan strategi inkuiri terbimbing yang menjadikan siswa lebih termotivasi dan mampu bekerjasamaalam pembelajaran.
2. Bagi siswa agar membiasakan diri bekerjasama dalam proses pembelajaran baik itu yang berkelompok maupun tidak, untuk berlatih saling memberi atau merima pendapat teman dan dalam menyelesaikan tugas-tugas kelompok diperlukan kerjasama.

3. Dalam rangka meningkatkan kualitas pendidikan khususnya penerapan strategi pembelajaran dan peningkatan hasil belajar siswa, pihak sekolah diharapkan melakukan penelitian lebih lanjut dengan teliti dan cermat terhadap pelaksanaan pembelajaran melalui strategi inkuiri terbimbing.

\section{DAFTAR RUJUKAN}

Efi. 2007. Cooperative Learning. wikispaces.com.

http://idb4.wikispaces.com

Landsberge, Joe. 2009. Cooplearn. Studygs. http://www.studygs.net/melayumanado.

Madya, Suwarsih. 2010. Penelitian Tindakan Kelas. http://agus.blogchandra.com /penelitian-tindakan-kelas

Nasution. 2000. Didaktik Asas-asas Mengajar. Jakarta: Bumi Aksara

Sanjaya, Wina. Dr. (2008). Strategi Pembelajaran Berorientasi Standar Proses Pendidikan. Jakarta: Kencana Prenada Media Group.

Sarwanto.2009. Penilaian Afektif. http://staf.uns.ac.idfiles/2009/penialaianafektif.ppt

Sriyono,dkk. 1992. Teknik Belajar Mengajar dalam CBSA. Jakarta: Rineka Cipta

Whandi. 2009. Profesionalisme Guru. http://www.infoskripsi.com/Article/ Profesiona lisme-Guru.html 